\title{
Urinary tract pathogens among inpatients at a large Italian tertiary care Hospital; a prospective monitoring study
}

Roberto Manfredi

From $16^{\text {th }}$ International Symposium on HIV and Emerging Infectious Diseases

Marseille, France. 24-26 March 2010

\section{Background}

A standardized, prospective microbiological surveillance study of urinary tract infection is ongoing at our Hospital.

\section{Methods}

The temporal trend of microbial isolates from urines of inpatients hospitalized during the last available calendar year (2008), was evaluated quarterly according to the main bacterial and fungal isolates. The same pathogens cultured more than once from the same patient within one month, have been considered only once.

\section{Results}

Of 2,327 overall episodes (as defined above), 983 (42.2\%) were determined by Escherichia coli, followed by Enterococcus fecalis (443 episodes: 19.0\%), Proteus mirabilis (156 cases: 6.7\%), Klebsiella spp. (152 episodes: 6.5\%), Pseudomonas aeruginosa (117 cases: 5.0\%), Enterococcus faecium (56 episodes: 2.4\%), while the first fungal pathogen was Candida albicans (70 episodes: 3.0\%). During the proportionally short observation period, no significant variations occurred in the frequency of isolation of each mentioned urinary tract pathogen, when excluding a mild increased frequency of Enterococcus faecium and Enterobacter cloacae $(p<.07)$.

\section{Discussion}

A prospective microbiological observation study significantly adds to the knowledge of local epidemiological figures and antimicrobial susceptibility pattern of hospital-associated infections, including urinary tract

Correspondence: Roberto.manfredi@unibo.it

Infectious Diseases, University of Bologna, S. Orsola Hospital, Bologna, Italy infections, which are responsible for considerable morbidity among inpatients. During the still limited (one year) observation time, modest variations occurred in the frequency of isolation of the most frequent microorganisms, with Escherichia coli representing over $40 \%$ of cultured organisms, followed by Enterococcus faecalis (which proved responsible of around $19 \%$ of overall episodes). The tendency towards an increased incidence of Enterococcus faecium and Enterobacter cloacae is of concern, given the unpredictable antibiotic sensitivity profile of these last microorganisms.

Published: 11 May 2010

doi:10.1186/1742-4690-7-S1-P174

Cite this article as: Manfredi: Urinary tract pathogens among inpatients at a large Italian tertiary care Hospital; a prospective monitoring study. Retrovirology 2010 7(Suppl 1):P174.

Submit your next manuscript to BioMed Central and take full advantage of:

- Convenient online submission

- Thorough peer review

- No space constraints or color figure charges

- Immediate publication on acceptance

- Inclusion in PubMed, CAS, Scopus and Google Scholar

- Research which is freely available for redistribution

Submit your manuscript at www.biomedcentral.com/submit 